\title{
A Study on Job Stastification of Cognizant Employe's in Chennai
}

Manuscript ID:

MGT-2021-09024145

Volume: 9

Issue: 2

Month: October

Year: 2021

P-ISSN: 2321-4643

E-ISSN: 2581-9402

Received: 20.07.2021

Accepted: 25.09.2021

Published: 01.10.2021

Citation:

Krishnamoorthy, A. "A Study on Job Stastification of Cognizant Employe's in Chennai." Shanlax International Journal of Management, vol. 9, no. 2, 2021, pp. 31-36.

\section{DOI:}

https://doi.org/10.34293/ management.v9i2.4145

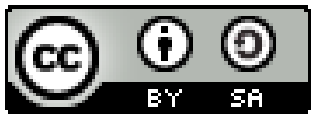

This work is licensed under a Creative Commons Attribution-ShareAlike 4.0 International License.

\author{
A. Krishnamoorthy \\ Assistant Professor, Department of Commerce \\ School of Arts and Science, AVIT Campus, Chennai, Tamil Nadu, India
}

\section{Abstract}

Job satisfaction is the primary pillar of any organisation, job satisfaction of well means the company production to profit also in the organisation. This study confined to produce the satisfaction levels of the Cognizant privatel. They were limited during the study. Problem Statement one of the main roles of Human Resources (HR) departments is to ensure that employees are sufficiently satisfied with their jobs. The data requirements for this study were mainly. Primary data from cognizant employee's in Chennai. The study is based on primary, secondary data. This study made of percentage analysis.

Keywords: Human resources, Employee, Psychology, Organisation, Private

\section{Introduction}

Job satisfaction is related to the psychology of an employee. A happy \& content employee at a job is always motivated to contribute more. On the other hand, a dissatisfied employee is lethargic, makes mistakes \& becomes a burden to the company ${ }^{2}$. The elements \& factors which contribute to job satisfaction are Compensation \& Working conditions. One of the biggest factors of job satisfaction is the compensation and benefits given to an employee. An employee with a good salary, incentives, bonuses, healthcare options etc., is happier with their job than someone who doesn't have the same. A healthy workplace environment also adds value to an employee. Work-life balance: Every individual wants to have good workplaces which allow them time to spend with their family \& friends. Job satisfaction for employees is often due to a good work-life balance policy, which ensures that an employee spends quality time with their family and doing their work. This improves the employee's quality of work life. Respect \& Recognition: Any individual appreciates and feels motivated if they are respected at their workplace. Also, if they are awarded for their hard work, it further motivates employees. Hence recognition is one of the job satisfaction factors. Job securities: If an employee is assured that the company would retain them even if the market is turbulent, it gives them immense confidence. Job security is one of the main reasons for job satisfaction for employees. Challenges: Monotonous work activities can lead to dissatisfied employees. Hence, things like job rotation, job enrichment etc., can help in the job satisfaction of employees. Career Growth: Employees always keep their career growth part as a high priority in their life.

1 https://www.coursehero.com/file/9254183/Job-Satisfaction.

2 Lise M. Saari and Timothy A. Judge," Employee Attitudes And Job Satisfaction"., Human Resource Management, Winter 2004, Vol. 43, No. 4, Pp. 395-407 (C) 2004 Wiley Periodicals, Inc. Published online in Wiley InterScience (www.interscience.wiley.com). DOI: 10.1002/hrm.20032. 
Hence, if a company helps groom employees and gives them newer job roles, it enhances job satisfaction as they know they would get a boost in their career.

\section{Statement of the Problem}

Job satisfaction is the primary pillar of any organisation, job satisfaction of well means the company production to profit also in the organisation. This study confined to produce the satisfaction levels of the Cognizant private limited $^{2}$ during the study. Problem Statement One of the main roles of Human Resources (HR) departments is to ensure that employees are sufficiently satisfied with their jobs. Typically research has shown that satisfied employees or corporations are thought to be more productive. On the other hand, if workers are dissatisfied with their jobs, they are less productive and more prone to absenteeism and turnover. So HR departments need to measure employee job satisfaction and examine the correlations between these three variables (productivity, absenteeism, and turnover) about possible extraneous variables. Human Resources Consulting, Inc. is hired by a medium-sized financial firm to conduct a survey address.

\section{Objective}

- To find the job satisfaction level of Cognizant Employee's In Chennai

- To find out the findings regarding the study.

\section{Data Collection and Analysis}

The data requirements for this study were mainly. Primary data from cognizant employee's in Chennai. The study is based on primary, secondary data, in this study made of percentage analysis.

Table 1: How Long you have been Working in the Industry

\begin{tabular}{|l|c|c|}
\hline \multicolumn{1}{|c|}{ Particulars } & No .of. Respondent & $\mathbf{\%}$ \\
\hline less than 3 & 45 & 45 \\
\hline 3-5 years & 30 & 30 \\
\hline more than 5 years & 25 & 25 \\
\hline Total & $\mathbf{1 0 0}$ & $\mathbf{1 0 0}$ \\
\hline
\end{tabular}

Source: Computed from primary data 3 https://www.coursehero.com/file/9254183/ Job-Satisfaction.
To job satisfaction of cognizant company the calculate data value of 25 per cent, it shows that more than 5 of despondence with respective number respondent was 25 per cent. It is the lower chapter value of the table the calculate value of 45 per cent was who those less than 3years of the respondent with respective numbers 45 per cent it is the highest value of the table.

Table 2: How do you Feel the Working Environment

\begin{tabular}{|c|c|c|}
\hline Option & Respondent & $\%$ \\
\hline Excellent & 50 & 50 \\
\hline Good & 35 & 35 \\
\hline satisfactory not satisfactory & 15 & 15 \\
\hline Total & 100 & 100 \\
\hline
\end{tabular}

Source: Computed from primary data

To job satisfaction of cognizant company the calculate data value of 50 per cent, it shows that more than 15 of despondence with respective number respondent was 50 per cent. It is the lower chapter value of the table the calculate value of 50 per cent was who those less than respondent with respective numbers 50 per cent it is the highest value of the table.

Table 3: How Secure do you Feel in your Job

\begin{tabular}{|l|c|c|}
\hline \multicolumn{1}{|c|}{ Option } & Respondent & $\mathbf{\%}$ \\
\hline High secure & 65 & 65 \\
\hline Secure & 25 & 25 \\
\hline Insecure & 10 & 10 \\
\hline \multicolumn{1}{|c|}{ Total } & $\mathbf{1 0 0}$ & $\mathbf{1 0 0}$ \\
\hline
\end{tabular}

Source: Computed from primary data

To job satisfaction of the cognizant company, the calculated data value of 65 per cent high secure shows that more than 15 per cent of insecure despondence with respective number respondent was 50 per cent. It is the lower chapter value of the table the calculate value of 50 per cent was who those less than respondent with respective numbers 50 per cent it is the highest value of the table. 
Table 4: How do you Feel the Smooth Relationship with your Employers and Co-workers

\begin{tabular}{|l|c|c|}
\hline \multicolumn{1}{|c|}{ Option } & Respondent & $\mathbf{\%}$ \\
\hline very high & 40 & 40 \\
\hline High & 30 & 30 \\
\hline medium & 25 & 25 \\
\hline Low & 05 & 05 \\
\hline \multicolumn{1}{|c|}{ Total } & $\mathbf{1 0 0}$ & $\mathbf{1 0 0}$ \\
\hline
\end{tabular}

Source: Computed from primary data

To job satisfaction of cognizant company employee's smooth relationship of 40 per cent very high secure, it shows that more than 05 per cent of low despondence with respective number respondent was 40 per cent. It is the lower chapter value of the table the calculate value of 40 per cent was who those less than respondent with respective numbers 40 per cent it is the highest value of the table.

Table 5: Opinion about your Job

\begin{tabular}{|l|c|c|}
\hline \multicolumn{1}{|c|}{ Option } & Respondent & $\mathbf{\%}$ \\
\hline Highly satisfied & 40 & 40 \\
\hline Satisfied & 35 & 35 \\
\hline $\begin{array}{l}\text { Others } \\
\text { (specify) }\end{array}$ & 20 & 20 \\
\hline Not satisfied & 05 & 05 \\
\hline \multicolumn{1}{|c|}{ Total } & $\mathbf{1 0 0}$ & $\mathbf{1 0 0}$ \\
\hline
\end{tabular}

Source: Computed from primary data

To job satisfaction of cognizant company employee's opinion in our job40 per cent highly satisfied it shows that more than 05 per cent of not satisfied despondence with respective number respondent was 40 per cent. It is the lower chapter value of the table the calculate value of 40 per cent was who those less than respondent with respective numbers 40 per cent it is the highly satisfying value of the table.

Table 6: Are you Satisfied with the Appreciation or Reward System provided by your

\section{Management}

\begin{tabular}{|c|c|c|}
\hline Particular & Respondent & $\mathbf{\%}$ \\
\hline Highly satisfied & 65 & 65 \\
\hline
\end{tabular}

\begin{tabular}{|l|c|c|}
\hline Satisfied & 25 & 25 \\
\hline Needs improvement & 10 & 10 \\
\hline \multicolumn{1}{|c|}{ Total } & $\mathbf{1 0 0}$ & $\mathbf{1 0 0}$ \\
\hline
\end{tabular}

Source: Computed from primary data

To job satisfaction of cognizant company employee's appreciation or reward of 65 per cent highly satisfied it shows that more than 10 per cent of needs improvement despondence with respective number respondent was 65 per cent. It is the lower chapter value of the table the calculate value of 65 per cent was who those less than respondent with respective numbers 65 per cent it is the highly satisfying value of the table.

Table 7: Are you Satisfied with the Bonus and Incentives Given

\begin{tabular}{|l|c|c|}
\hline \multicolumn{1}{|c|}{ Option } & Respondent & $\mathbf{\%}$ \\
\hline Highly satisfied & 55 & 55 \\
\hline Satisfied & 35 & 35 \\
\hline Needs improvement & 10 & 10 \\
\hline \multicolumn{1}{|c|}{ Total } & $\mathbf{1 0 0}$ & $\mathbf{1 0 0}$ \\
\hline
\end{tabular}

Source: Computed from primary data

To job satisfaction of the cognizant company, employee's satisfied with the bonus and incentives are given of 55 per cent highly satisfied. It shows that more than 10percent of needs improvement despondence with respective number respondent was 65 per cent. It is the lower chapter value of the table the calculate value of 65 per cent was who those less than respondent with respective numbers 65 per cent it is the highly satisfying value of the table.

Table 8: Are you Satisfied with the Overall Compensation Package

\begin{tabular}{|l|c|c|}
\hline \multicolumn{1}{|c|}{ Option } & Respondent & $\mathbf{\%}$ \\
\hline Highly satisfied & 50 & 50 \\
\hline Satisfied & 35 & 35 \\
\hline Needs improvement & 15 & 15 \\
\hline \multicolumn{1}{|c|}{ Total } & $\mathbf{1 0 0}$ & $\mathbf{1 0 0}$ \\
\hline
\end{tabular}

Source: Computed from primary data

To job satisfaction of the cognizant company, employee's satisfied with the overall compensation 
package of 50 per cent highly satisfied it shows that more than 15percent of needs improvement despondence with respective number respondent was 65 per cent. It is the lower chapter value of the table the calculate value of 65 per cent was who those less than respondent with respective numbers 65 per cent it is the highly satisfying value of the table.

\section{Table 9: How do you Feel about the Welfare Scheme of your Showroom}

\begin{tabular}{|c|c|c|}
\hline Particular & Respondent & $\%$ \\
\hline Highly satisfied & 65 & 65 \\
\hline Satisfied & 25 & 25 \\
\hline Needs improvement & 10 & 10 \\
\hline Total & 100 & 100 \\
\hline
\end{tabular}

Source: Computed from primary data

To job satisfaction of cognizant company employee's feel about the welfare scheme of your showroom of 65 per cent highly satisfied it shows that more than 10percent of needs improvement despondence with respective number respondent was 65 per cent. It is the lower chapter value of the table the calculate value of 65 per cent was who those less than respondent with respective numbers 65 per cent it is the highly satisfying value of the table.

\section{Finding}

1. Table 4.1 shows that to job satisfaction of cognizant company the calculate data value of 25 per cent it shows that more than 5 of despondence with respective number respondent was 25 per cent. the number of respondents $45 \%$ people who those work in the organisation of less than 3years

2. Table 4.2 shows that To job satisfaction of cognizant company the calculate data value of 50 per cent it shows that more than 15 of despondence with respective number respondent was 50 per cent. he number of respondent $50 \%$ excellent employee who those work in the organisation

3. Table 4.2 shows that to job satisfaction of cognizant company the calculate data value of 65 per cent high secure. It shows that more than 15 per cent of insecure respondence with respective number of respondent was 50 per cent. the number of respondents $65 \%$ high secure employee who those work in this company
4. The table shows that to job satisfaction of cognizant company employee's smooth relationship of 40 per cent very high secure it shows that more than 05 per cent of low correspondence with respective number respondent was 40 per cent. the number of respondents $05 \%$ not satisfied employee's work in the same organisation

5. The table shows that to job satisfaction of cognizant company employee's opinion in our job 40 per cent highly satisfied it shows that more than 05 per cent of not satisfied respondence with respective number respondent was 40 per cent. the number of respondent job opinion in $65 \%$ highly satisfied people work in the organisation

6. The table shows that to job satisfaction of cognizant company employee's appreciation or reward of 65 per cent highly satisfied it shows that more than 10 per cent of needs improvement respondence with respective number respondent was 65 per cent. the number of respondents $65 \%$ highly satisfied appreciation people work in this company

7. The table shows that to job satisfaction of cognizant company employees satisfied with the bonus and incentives given of 55 per cent highly satisfied it shows that more than 10 per cent of needs improvement respondence with respective number respondent was 65 per cent. the number of respondents $55 \%$ people highly satisfied with the incentive and bonus in the company

8. The table shows that to job satisfaction of cognizant company employee's satisfied with the overall compensation package of 50 per cent highly satisfied it shows that more than 15 per cent of needs improvement respondence with respective number respondent was 65 per cent need's improvement of overall compositions $50 \%$ highly satisfied employee.

9. The table shows that to job satisfaction of cognizant company employee's feel about the welfare scheme of your showroom of 65 per cent highly satisfied it shows that more than 10 per cent of needs improvement respondence with respective number respondent was 65 per cent. the number of respondents $65 \%$ of highly satisfied Employee's welfare scheme

10. The table shows that to job satisfaction of 
cognizant company employee's feel about the welfare scheme of your showroom of 65 per cent highly satisfied it shows that more than 10 per cent of needs improvement respondence with respective number respondent was 65 per cent. Employee's observed or experienced the number of respondents $45 \%$ of age discrimination in the company.

11. The table shows that to job satisfaction of cognizant company employee's factors which motivates you most of 35 per cent salary increase it shows that more of 20 per cent promotion with respective number respondent was 30 per cent motivational talks. the number of respondents $35 \%$ salary increase most factor motivation of the company

12. The table shows that to job satisfaction of cognizant company employee's got appreciation in the form of 45 per cent promotion it shows that more than 10 per cent of any other please specify respondence with respective number respondent was 45 per cent. the number of respondents $45 \%$ promotion of got appreciation in the organisation

13. The table shows that to job satisfaction of cognizant company employee's participate in functional meetings of 45 per cent sometimes it shows that more than 05 per cent of never respondence with respective number respondent was 45 per cent. Employees participate in functional meetings the number of respondents $45 \%$ in sometimes.

14. The table shows that to job satisfaction of cognizant company employee's given a chance to express your opinion of 50 per cent sometimes it shows that more than 05 per cent of never respondence with respective number respondent was 50 per cent. the number of respondents $50 \%$ of given a chance to express employee's opinion

15. The table shows that to job satisfaction of cognizant company employee's feel your opinions/views are regarded 35 per cent all the time. It shows that more than 05 per cent of never respondence with respective number respondent was 35 per cent. The number of respondents $35 \%$ of views or regarded in your opinion

16. The table shows that to job satisfaction of cognizant company employee's given due credit for your opinion/suggestions 45 per cent all the time it shows that more than 05percent of never respondence with respective number respondent was 45 per cent. The employee's opinion and suggestions in the respondent of $45 \%$ in the company

17. The table shows that to job satisfaction of cognizant company employee's feel that there are chances for your career growth in the organisation 40 per cent often it shows that more than 05percent of never respondence with respective number respondent was 40 per cent. The number of respondents $40 \%$ employee's career growth in the organisation

\section{Conclusion}

The study results that the majority of the employees and aware of the organisation objective and the company policy. From the study, it is clear that anchor leathers have excellent processing line, reputation, infrastructure facilities etc., organisation financial structure are highly satisfied by the employees. Certainly, this concern will yield and retain good performance in future by considering the suggestions given by the researcher. Hence the project entitled "a study on employee's job satisfaction with special reference to a-bond strands Pvt. 1td". Exhibits employees of the organisation are well satisfied with their human resource policies provided by the organisation.

\section{References}

Austin, Tommye. Relationship between Nurse Leader Emotional Intelligence and Registered Nurse Job Satisfaction. The University of Texas Health Science Center at Houston, 2011.

Banerji, Priyanka, and Venkat Krishnan. "Ethical Preferences of Transformational Leaders: An Empirical Investigation." Leadership \& Organization Development Journal, vol. 21, no. 8, 2000, pp. 405-413.

Berl, Robert L., et al. "Industrial Salesforce Motivation: A Critique and Test of Maslow's Hierarchy of Need." Journal of Personal Selling and Sales Management, vol. 4, no. 1, 1984, pp. 32-39. 
Bigley, George, and Jone L. Pearce. "Straining for Shared Meaning in Organization Science: Problems of Trust and Distrust." Academy of Management Review, vol. 23, no. 3, 1998, pp. 405-421.

Beslin, Ralph, and Chitra Reddin. "How Leaders can Communicate to Build Trust." Ivey Business Journal, 2004.

Caldwell, Cam. "Book Review Essay: Building Trust through Effective Governance - Three Perspectives of Organizational Leadership." Academy of Management Review, vol. 28, no. 4, 2003.

Cook, John, and Toby Wall. "New Work Attitude Measures of Trust, Organizational Commitment and Personal Need NonFulfillment." Journal of Occupational Psychology, vol. 53, no. 1, 1980, pp. 39-52.

Daley, Dennis M., and Michael L. Vasu. "Fostering Organizational Trust in North Carolina: The Pivotal Role of Administrators and Political Leaders." Administration \& Society, vol. 30, no. 1,1998 , pp. $62-84$.
Dirks, Kurt T., and Donald L. Ferrin. "Trust in Leadership: Meta-analytic Findings and Implications for Research and Practice." Journal of Applied Psychology, vol. 87, no. 4, 2002, pp. 611-628.

Frauenheim, Ed. "5 Questions for Stephen M.R. Covey." Workforce, 2006.

Hackman, J. Richard, and Greg R. Oldham. "Motivation through the Design of Work: Test of Theory." Organisational Behaviour and Human Performance, vol. 16, no. 2, 1975, pp. 250-279.

Ismail, Azman, et al. "Relationship between Performance based Pay, Interactional Justice and Job Satisfaction: A Mediating Model Approach." International Journal of Business and Management, vol. 6, no. 11, 2011.

Saari, Lise M., and Timothy A. Judge. "Employee Attitudes and Job Satisfaction." Human Resource Management, vol. 43, no. 4, 2004, pp. 395-407.

\section{Author Details:}

Dr. A. Krishnamoorthy, Assistant Professor, Department of Commerce, School of Arts and Science, AVIT Campus, Chennai, Tamil Nadu, India, Email ID: kmoorthy281@gmaill.com 